\title{
The distribution and occurrence of mercury in Chinese coals
}

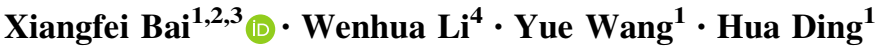

Received: 16 May 2016/Revised: 7 March 2017/Accepted: 3 April 2017/Published online: 13 April 2017

(C) The Author(s) 2017. This article is an open access publication

\begin{abstract}
Mercury is one of the most concerned hazardous elements in coals. 1018 coal samples of different coal-forming periods, coal-accumulating areas and coal ranks all over the country were collected to study the distributions of mercury in Chinese coals. The modes of occurrence of mercury were studied with float-sink experiments of 10 coals from different basins in China and correlation analyses were conducted between concentrations of mercury and maceral and sulfur contents, as well as the ash yield. The theoretic concentrations and affinities of mercury in vitrinite, inertinite, clay and pyrite were then calculated following the methods proposed by Solari. The weighted average concentration of mercury in Chinese coals is $0.154 \mu \mathrm{g} / \mathrm{g}$, which is similar to that in the word coals in general. The mercury concentrations vary largely in the coals of different coal-forming period and coal-accumulating areas as geological settings play key roles in determining the geochemistry of mercury. The concentrations of mercury in coals from south and southwest China and those from North China of $\mathrm{C}_{3}-\mathrm{P}_{1}$ are relatively higher while those from North China of $\mathrm{J}_{1-2}$ and Northeast of $\mathrm{J}_{3}-\mathrm{K}_{1}$ relatively lower. The general distribution trends of mercury are very similar to that of ash yield, sulfur contents in coals. Pyrite is the dominant carrier of mercury in most coals, especially in some high-sulfur coals with abundant epigenetic pyrite formed during diagenesis and metamorphism. Mercury has higher affinity to vitrinite than to inertinite in most coals, which accords with the geological origin of macerals and geochemistry of mercury.
\end{abstract}

Keywords Coal $\cdot$ Mercury $\cdot$ Concentration $\cdot$ Distribution $\cdot$ Modes of occurrence

\section{Introduction}

Mercury is an excellent proxy for periods of major volcanic activity in the geological record (Grasby et al. 2015; Thibodeau et al. 2016). Organic matters strongly control

Xiangfei Bai

bxf1970@sina.com

1 Beijing Research Institute of Coal Chemistry, China Coal Research Institute, Beijing 100013, China

2 State Key Laboratory of Coal Mining and Clean Utilization, Beijing 100013, China

3 College of Environmental Engineering, North China Institute of Science and Technology, Beijing 101601, China

4 National Institute of Clean-and-low-Carbon Energy, Beijing 102209, China mercury sequestration over geological time (Grasby et al. 2013). Terrestrial mercury of atmospheric origin may potentially be transported to coastal sediments bound to organics or clay particles (Sanei and Goodarzi 2006; Outridge and Sanei 2010; Sanei et al. 2010; Kongchum et al. 2011; Sanei et al. 2014). As a highly toxic element (Yudovich and Ketris 2005; Dai et al. 2012b), mercury is a chemical of global concern owing to its long-range atmospheric transport and its persistence in the environment. Once emitted into the atmosphere, mercury can be transformed into highly toxic methyl-Hg in aquatic ecosystems and the living organisms can be affected by bio-accumulations (Fitzgerald et al. 1998). The mercury concentration in the atmosphere has increased by $250 \%$ while the mercury in surface water $25 \%$ and in deep sea $11 \%$ since the industrial revolution (Sunderland and Mason 
2006). The increasing industrialization in Asia has made it the largest regional mercury emissions source into the atmosphere, with east and southeast Asia accounting for about $40 \%$ of the total global anthropogenic mercury emissions (UNEP Chemicals Branch 2013).

The human activities are responsible for the inventory of global mercury. Coal combustion has been proven the largest anthropogenic sources of atmospheric mercury emissions (Galbreath and Zygarlicke 2000; Pacyna et al. 2006, 2010; Wilcox et al. 2012; Huang et al. 2016). The annual anthropogenic emission of mercury is estimated at nearly $31 \%$ of its total emissions (Pirrone et al. 2010) while coal burning for mercury emission is 475 tons in 2010 (UNEP Chemicals Branch 2013). About 100 tons of mercury are emitted into atmosphere from coal-fired power plants in China every years (Tang et al. 2016).

Extensive efforts have been made to control mercury emissions worldwide. The Minamata Convention on Mercury, the world's first legally binding treaty on reducing the mercury pollution, was signatured in 2013 under the endeavors of the United Nations Environment Program (UNEP) (UNEP 2013). Mercury has been listed as one of potential hazardous elements in the United States of America since the Clean Air Act Amendment was carried out in 1990. Mercury and Air Toxics Standards (MATS) was issued a final finding by the U.S. Environmental Protection Agency (EPA) for reducing emission of toxic air pollutants from power plants in April 14, 2016.

As the largest user and emitter of mercury, China faces extraordinary challenges. The limits of mercury concentration for coal-fired power plant flue gas was set at less than $0.03 \mathrm{mg} / \mathrm{Nm}^{3}$ according to the Chinese standard GB/T 13223-2011. The distribution and occurrence of mercury in coals from various coal basins in China had been reported intensively (Dai and Ren 2007; Liu et al. 2007; Song et al. 2007; Wang et al. 2007; Zheng et al. 2007, 2008; Li et al. 2012; Jiang et al. 2015), especially those with higher content of mercury from Southwest China (Dai et al. 2006a, 2008; Wang 2009; Wang et al. 2012; Zhuang et al. 2012; Dai et al. 2013a, b, 2014; Chen et al. 2015; Li et al. 2016).

The modes of occurrence of mercury in coal are of growing concern. The confident level of mercury occurrence in coal was estimated 6 out of 10 (Finkelman 1994). It is generally considered that mercury can be presented in coal as sulfide and selenides, in forms associated with pyrite and marcasite (Ward et al. 1999; Hower et al. 2008; Kolker 2012), calcite and chlorite (Zhang et al. 2002), selenio-galena (Dai et al. 2006b, 2015), clausthalite (Hower and Robertson 2003), kleinite and cinnabar (Brownfield et al. 2005), sphalerite $\left(\mathrm{HgFeS}_{2}\right)$ and getchellite (Dai et al. 2006a). It can also organically bounded to organic matter (HgOM) (Rumayor et al. 2015), or even as $\mathrm{HgS}$ and metallic mercury $\left(\mathrm{Hg}^{0}\right)$
(Finkelman 1994; Yudovich and Ketris 2005). It is clear that mercury is mostly associated with pyrite, especially late-stage (epigenetic) pyrite deposited from hydrothermal basinal fluids (Hower et al. 2007; Dai et al. 2012a; Diehl et al. 2012; Kolker 2012). Besides, Mercury derived from the igneous intrusion distributed in both the organic matter and the minerals (Dai et al. 2012c). Syngenetic hydrothermal solutions were input during peat accumulation and thus led to high mercury concentrations in all the coal benches (Dai et al. 2013a). Mercury may re-deposited from the solutions and were adsorbed in the coal when the temperatures dropped to ambient levels (Finkelman et al. 1998). Mercury could also be driven off from the organic component in the coal by magmatic heat and then re-deposited nearby. So the concentrations of mercury are higher in altered coals near magmatic intrusions (Finkelman et al. 1998; Golab and Carr 2004; Dai and Ren 2007; Dai et al. 2012c).

The mercury concentrations of more than 1000 coal samples systematic collected around the country are determined to study the concentration and distribution characteristics of mercury in Chinese coals in this paper. Then, the modes of occurrence of mercury are studied with float-sink experiments of 10 representative coals of different rank from different basins in China and correlation analyses.

\section{Sampling and methods}

\subsection{The distribution of mercury in Chinese coals}

\subsubsection{Coal sampling}

The main coal-forming periods in China are Early Carboniferous $\left(\mathrm{C}_{1}\right)$, Late Carboniferous $\left(\mathrm{C}_{3}\right)$, Early Permian $\left(\mathrm{P}_{1}\right)$, Late Permian $\left(\mathrm{P}_{2}\right)$, Triassic $(\mathrm{T})$, Early- Middle Jurassic $\left(\mathrm{J}_{1-2}\right)$, Late Jurassic to Early Cretaceous $\left(\mathrm{J}_{3}-\mathrm{K}_{1}\right)$, Eogene (E). The geological distribution of coals in China can be divided into four main coal-accumulating areas, which are North China, Northeast China, Northwest China, South China and Southwest China. The sedimentary characteristics, coal-bearing properties and the coal qualities are quite different in different coal-accumulating areas (Mao and Xu 1999).

1018 coal samples covering the main coal-forming periods and the main coal-accumulating areas, were systematically collected to study the distribution of mercury in Chinese coals. The coal samples were collected continuously from the top to bottom of a coal seam with dimensions of $5 \mathrm{~cm} \times 5 \mathrm{~cm}$ following ISO standard (ISO 18283:2006 Hard coal and coke-manual sampling). The geological and geographical distributions of the samples 
Table 1 The geological and geographical distribution of the samples

\begin{tabular}{|c|c|c|c|c|c|c|c|c|c|c|}
\hline \multirow[t]{2}{*}{ District } & \multirow[t]{2}{*}{ Province } & \multicolumn{8}{|c|}{ Coal-forming period } & \multirow[t]{2}{*}{ Number of samples } \\
\hline & & $\mathrm{E}$ & $\mathrm{J}_{3}-\mathrm{K}_{1}$ & $\mathrm{~J}_{1-2}$ & $\mathrm{~T}_{3}$ & $\mathrm{P}_{2}$ & $\mathrm{P}_{1}$ & $\mathrm{C}_{3}$ & $\mathrm{C}_{1}$ & \\
\hline \multirow[t]{9}{*}{ North China } & Beijing & & & 11 & & & & & & 11 \\
\hline & Hebei & & & 3 & & & 41 & 40 & & 84 \\
\hline & Henan & & & 13 & & & 82 & 1 & & 96 \\
\hline & Jiangsu & & & & & & 15 & 3 & & 18 \\
\hline & Neimenggu & & 30 & 13 & & & 11 & 12 & & 66 \\
\hline & Ningxia & & & & & & 12 & 22 & & 34 \\
\hline & Shaanxi & & & 2 & & & 3 & 6 & & 11 \\
\hline & Shandong & 3 & & 2 & & & 25 & 33 & & 63 \\
\hline & Shanxi & & & 29 & & & 30 & 27 & & 86 \\
\hline \multirow[t]{3}{*}{ Northeast China } & Heilongjiang & & 62 & & & & & & & 62 \\
\hline & Jilin & 12 & 4 & & & & 4 & 1 & & 21 \\
\hline & Liaoning & 4 & 22 & 10 & & & 8 & 2 & & 46 \\
\hline \multirow[t]{3}{*}{ Northwest China } & Gansu & & & 20 & & & & & & 20 \\
\hline & Qinhai & & & 4 & & & & & & 4 \\
\hline & Xinjiang & & & 39 & & & & & & 39 \\
\hline \multirow[t]{10}{*}{ South and Southwest China } & Guizhou & & & & & 48 & & & & 48 \\
\hline & Yunnan & & & & 3 & 14 & & & & 17 \\
\hline & Fujian & & & & 2 & & & & & 2 \\
\hline & Guangdong & & & & & 33 & & & & 33 \\
\hline & Guangxi & 30 & & & & 48 & & & & 78 \\
\hline & Hubei & & & & & 19 & & & & 19 \\
\hline & Hunan & & & & 11 & 7 & & & 14 & 32 \\
\hline & Jiangxi & & & & 31 & 33 & & & & 64 \\
\hline & Sichuan & & & & 20 & 39 & & & & 59 \\
\hline & Zhejiang & & & & & 5 & & & & 5 \\
\hline
\end{tabular}

are shown in Table 1. The samples studied are well representative of the coal resource in China.

\subsubsection{Analyses}

The proximate analyses of the samples were determined according to ISO 11722:1999, ISO 1171:1997 and ISO $562: 1998$. Total sulfurs of the samples were determined according to ISO $351: 1996$. The coal ranks were determined according to the Chinese standard GB/T 5751-2009. The concentrations of mercury were determined by coldvapor atomic absorption spectrometry (CV-AAS) using a Milestone DMA-80 $\mathrm{Hg}$ analyzer following ISO 15237: 2003. All those tests were conducted in Beijing Research Institute of Coal Chemistry, China Coal Research Institute. The precisions and accuracy of the determinations conform to the requirements of the standards.

Then the concentration and distribution characteristics of mercury based on coal-forming periods, coal-accumulating areas, coal ranks were discussed. The relationships between the mercury concentrations and sulfur contents, as well as the ash yield, were also analyzed.

\subsection{The modes of occurrence of mercury}

\subsubsection{Coal sampling and density separation}

Considering the characteristics of coal-forming periods, sedimentary basin types, coal properties in China, 10 steam coals consumed in large scale in China were chosen to study the modes of occurrence of mercury in Chinese coals. The main characteristics of the samples are shown in Table 2 and details are described by Bai (2003). The sampling procedures were as the same as in 2.1.1. The samples were divided into two parts, one for the basic analyses (see Table 6), the other for float-sink experiments.

The samples used for float-sink experiments were all crushed to less than $3 \mathrm{~mm}$ and the float-sink experiments were conducted following the Chinese standard GB/T 478-2008. Six density fractions, namely $<1.3,1.3-1.4$, 
Table 2 The representations of the 10 steam coal samples

\begin{tabular}{lllll}
\hline Sample & Coal-forming period & Coal seam & Coal rank & ISO 11760:2005 \\
\cline { 3 - 5 } & & & GB/T 5751-2009 & Low-rank A \\
\hline XLT & $\mathrm{N}$ & $\mathrm{N}_{1}^{3}$ & Lignite & Low-rank B \\
HLH & $\mathrm{J}_{3}-\mathrm{K}_{1}$ & No. 14 & Lignite & Medium-rank C \\
TF & $\mathrm{J}_{3}-\mathrm{K}_{1}$ & No. 4 & Gas coal & Low-rank A \\
YM & $\mathrm{J}_{1-2}$ & $1^{-2}$ & Long flame coal & Medium-rank D \\
SD & $\mathrm{J}_{1-2}$ & $2^{-2}$ & Long flame coal & Medium-rank C \\
DT & $\mathrm{J}_{1-2}$ & No. 10 & Geakly caking coal & Medium-rank C \\
PS & $\mathrm{P}_{1}$ & No. 4 & Long flame coal & Medium-rank D \\
HDG & $\mathrm{P}_{1}$ & No. 6 & Meager coal & Medium-rank A \\
CC & $\mathrm{P}_{1}$ & No. 4 & Gas coal & Medium-rank C \\
YZ & $\mathrm{C}_{3}$ & $16-17$ &
\end{tabular}

$1.4-1.5,1.5-1.6,1.6-1.8$ and $>1.8 \mathrm{~kg} / \mathrm{L}$, were obtained from each sample.

The proximate analyses, total sulfurs and the concentrations of mercury of the raw coals and products from density separations were determined as described in Chapter 2.1.1. The maceral compositions of products from density separations were determined by Zeiss Imager A2 m microscope according to ISO 7404-3 (Methods for the petrographic analysis).

\subsubsection{The modes of occurrence of mercury}

Correlation analyses between $\mathrm{Hg}$ and macerals, ash yield and sulfur contents were conducted using the raw coal and the six density fractions. Then the theoretical mercury content $\left(C_{i}\right)$ in the macerals and minerals was calculated by muti-factor linear regression following the method proposed by Solari et al. (1989). According to Solari, a linear relationship is found between the mercury concentrations in coal sample $(C)$ and in different macerals and minerals $\left(C_{i}\right)$. The theoretical mercury concentration in minerals and macerals were determined by Eq. (1):

$C=\sum_{i=1}^{n} C_{i} W_{i}$

where, $C$ is the mercury content in coal $(\mu \mathrm{g} / \mathrm{g}), C_{i}$ is the theoretical mercury content in minerals and macerals $(\mu \mathrm{g} /$ $\mathrm{g}), W_{i}$ is the maceral composition of the products of different densities (\%).

The affinities of mercury to vitrinite, inertinite and minerals $\left(A_{i}\right)$ can be subsequently calculated by Eq. (2):

$A_{i}=\frac{C_{i} W}{\sum_{i=1}^{n} C_{i} W_{i}} \times 100 \%$

where, $A_{i}$ is the affinity of mercury to vitrinite, inertinite and minerals.

\section{Results and discussion}

\subsection{The distributions of mercury in Chinese coals}

(1) The concentrations of mercury in Chinese coals

The statistical characteristics of mercury in Chinese coals are shown in Tables 3 and 4 . The histogram of mercury in

Table 3 The statistical characteristics of mercury in Chinese coals of different coal-forming periods

\begin{tabular}{llcll}
\hline $\begin{array}{l}\text { Coal-forming } \\
\text { period }\end{array}$ & $\begin{array}{l}\text { Range } \\
(\mu \mathrm{g} / \mathrm{g})\end{array}$ & $\begin{array}{l}\text { Number of } \\
\text { samples }\end{array}$ & $\begin{array}{l}\text { Arithmetic } \\
\text { mean }(\mu \mathrm{g} / \mathrm{g})\end{array}$ & $\mathrm{SD}$ \\
\hline $\mathrm{E}$ & $0-1.1$ & 49 & 0.214 & 0.211 \\
$\mathrm{~J}_{3}-\mathrm{K}_{1}$ & $0-0.8$ & 118 & 0.096 & 0.101 \\
$\mathrm{~J}_{1-2}$ & $0-2$ & 146 & 0.122 & 0.179 \\
$\mathrm{~T}_{3}$ & $0-6.2$ & 67 & 0.261 & 0.695 \\
$\mathrm{P}_{2}$ & $0-1.1$ & 246 & 0.221 & 0.186 \\
$\mathrm{P}_{1}$ & $0-1.1$ & 231 & 0.168 & 0.133 \\
$\mathrm{C}_{3}$ & $0-0.8$ & 147 & 0.199 & 0.158 \\
$\mathrm{C}_{1}$ & $0.1-0.4$ & 14 & 0.216 & 0.088 \\
\hline
\end{tabular}

Table 4 The statistical characteristics of mercury in Chinese coals of different districts

\begin{tabular}{lllll}
\hline District & $\begin{array}{l}\text { Range } \\
(\mu \mathrm{g} / \mathrm{g})\end{array}$ & $\begin{array}{l}\text { Number of } \\
\text { samples }\end{array}$ & $\begin{array}{l}\text { Arithmetic } \\
\text { mean }(\mu \mathrm{g} / \mathrm{g})\end{array}$ & $\mathrm{SD}$ \\
\hline $\begin{array}{c}\text { South and } \\
\text { Southwest }\end{array}$ & $0-6.2$ & 357 & 0.236 & 0.364 \\
$\begin{array}{c}\text { Northeast } \\
\begin{array}{c}\text { North China } \\
\mathrm{C}_{3}-\mathrm{P}_{1}\end{array}\end{array}$ & $0-0.8$ & 129 & 0.093 & 0.102 \\
$\begin{array}{c}\text { North China } \\
\mathrm{J}_{1-2}\end{array}$ & $0-2$ & 106 & 0.179 & 0.142 \\
$\begin{array}{c}\text { Northwest } \\
\text { orthes }\end{array}$ & $0-0.4$ & 63 & 0.148 & 0.225 \\
\hline
\end{tabular}


Chinese coals is shown in Fig. 1. The mercury concentrations from most Chinese coals range between 0 and $6.2 \mu \mathrm{g} /$ $\mathrm{g}$, with an arithmetic mean of $0.176 \mu \mathrm{g} / \mathrm{g}$, which is close to the results by Dai et al. (2012b) and a little higher than world coals (Clarke and Sloss 1992; Ketris and Yudovich 2009).

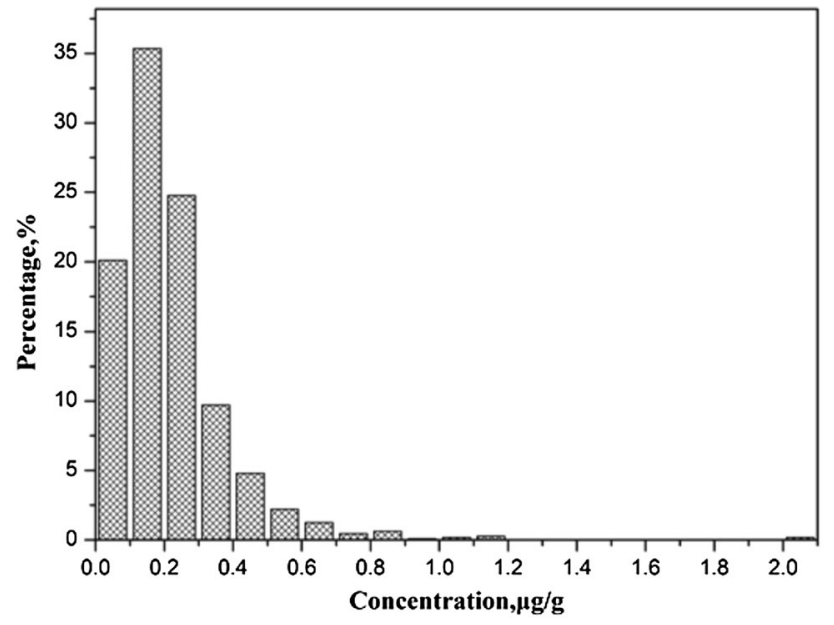

Fig. 1 The histogram of concentration of mercury in Chinese coals

Table 5 The concentrations of mercury in different rocks $(\mu \mathrm{g} / \mathrm{g})$

\begin{tabular}{lllll}
\hline $\begin{array}{l}\text { Average } \\
\text { concentration } \\
\text { in coal }\end{array}$ & $\begin{array}{l}\text { Abundance } \\
\text { in the crust }\end{array}$ & $\begin{array}{l}\text { Ultrabasic } \\
\text { rock }^{\mathrm{b}}\end{array}$ & Sandstone $^{\mathrm{b}}$ & Limestone $^{\mathrm{b}}$ \\
\hline 0.154 & 0.089 & 0.03 & 0.03 & 0.04 \\
\hline
\end{tabular}

${ }^{\mathrm{a}} \mathrm{Mu}(1999)$

${ }^{\mathrm{b}}$ Liu and Cao (1987)
There are some inconsistencies between the mean concentrations of mercury in Chinese coals proposed by different researchers (Zhang 1999; Huang and Yang 2002; Bai et al. 2007; Dai et al. 2012b). Actually, some coals from $P_{2}$ in the Southwest China and from $\mathrm{C}_{3}-\mathrm{P}_{1}$ in North China has been investigated intensively for their relatively or abnormally higher mercury concentrations and the related pollutions (Zhao 1997; Ren et al. 1999a; Zhao et al. 2002). But little researches has been carried out on coals of $J_{1-2}$ in the Northwest China with relatively low mercury concentrations as mentioned above, even though there are large quantities of coal resources. The objectivities of the results are deviated by the disproportion between samples studied and coal reserves in different regions when the arithmetic or geometric mean concentrations are used to assess the general distribution of mercury in Chinese coals.

As the coals in the same coal-accumulating basin share similar geological backgrounds and chemical properties (Mao and Xu 1999), it is reasonable to calculate the mercury concentrations by the combination of arithmetic means and the related coal reserves in different regions. The error from the disproportion between limited samples and their related reserves can be minimized when coal reserve-weighted factor is introduced. The weighted average concentration of mercury is determined as shown in Eq. (3):

$C_{m}=\frac{\sum_{i=1}^{5} C_{d i} W_{d i}}{\sum_{i=1}^{5} W_{d i}}$

where, $C_{m}$ is the weighted average concentration of mercury in Chinese coals $(\mu \mathrm{g} / \mathrm{g}), C_{d i}$ is the arithmetic means of mercury in coals from different coal-accumulating basin $(\mu \mathrm{g} / \mathrm{g}), W_{d i}$ is coal reserves in different regions $\left[\times 10^{8} \mathrm{t}\right.$, from Mao and Xu (1999)].

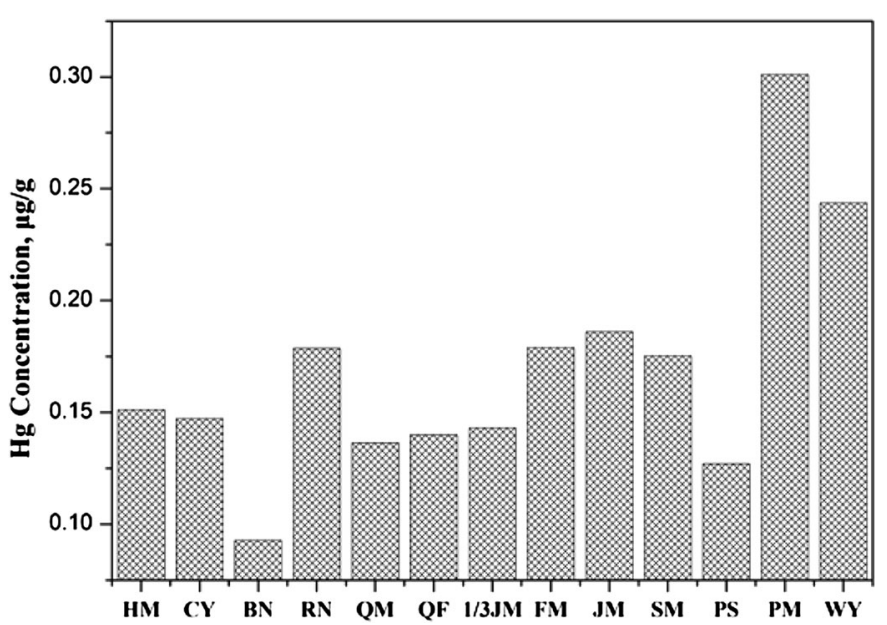

Fig. 2 The concentrations of mercury in coals of different ranks. Note HM, CY, BN, RN, QM, 1/3JM, FM, JM, SM, PS, PM, WY are the codes for brown coal, long flame coal, non-caking coal, weakly caking coal, gas coal, 1/3 coking coal, fat coal, primary coking coal, lean coal, meager lean coal, meager coal, anthracite respectively according to Chinese classification of coals 


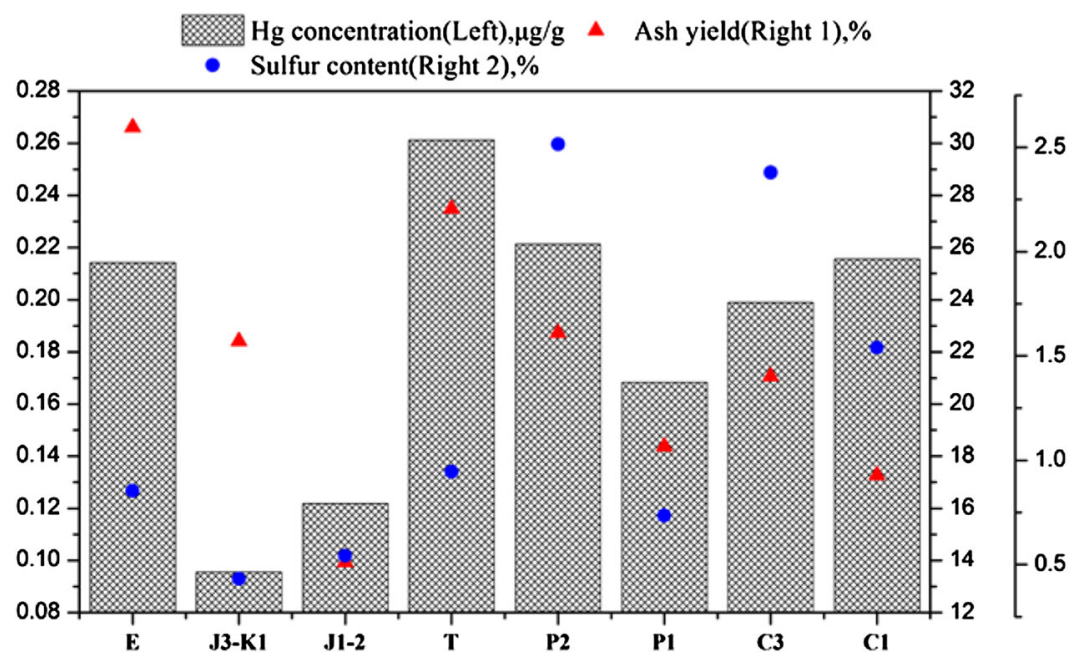

Fig. 3 The relationships between the mercury concentrations and ash yield, sulfur content in Chinese coals of different coal-forming periods

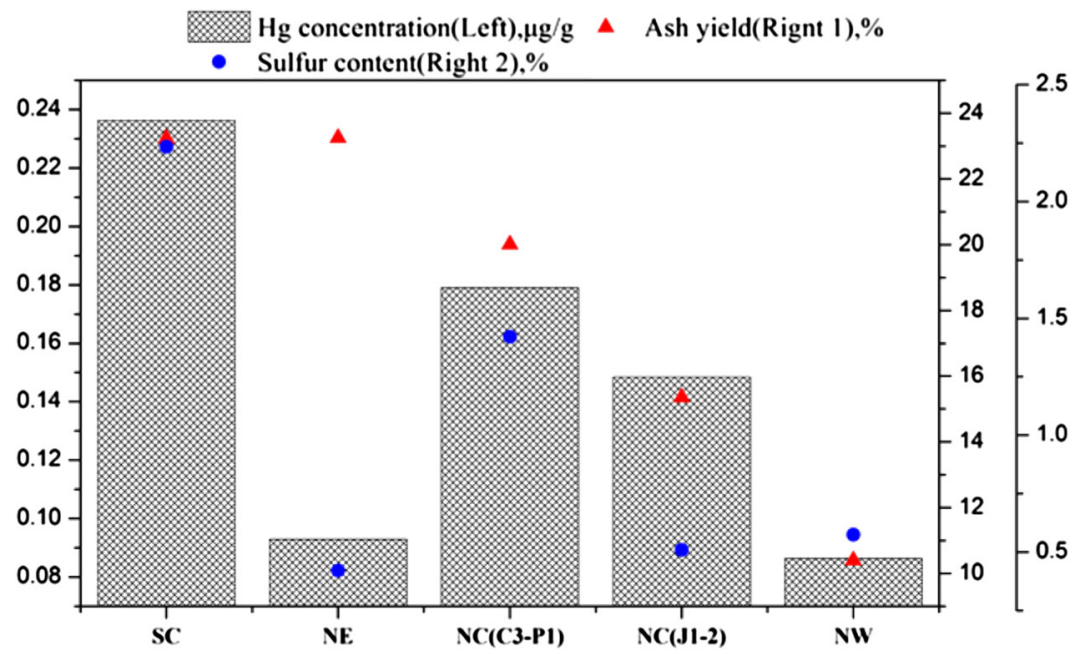

Fig. 4 The relationships between the mercury concentrations and ash yield, sulfur content in Chinese coals of different coal-accumulating areas (SC South and Southwest China, $N E$ Northeast China, $N C\left(C_{3}-P_{1}\right)$ North China $\mathrm{C}_{3}-\mathrm{P}_{1}, N C\left(J_{1-2}\right)$ North China $\mathrm{J}_{1-2}, N W$ Northwest China)

The weighted average concentration of mercury in Chinese coals is $0.154 \mu \mathrm{g} / \mathrm{g}$ as illuminated in Table 5 . Enrichment factors (EF) as shown in Eq. (4) (Ren et al. 1999a), can be used to indicate the enrichment of trace elements in coals. The concentration of mercury in Chinese coals is higher than that in the crust of the Earth, with the EF value up to 7.08. So the control of mercury pollution during coal exploitation and utilization should be emphasized, not only for its enrichment in coals but also for the much larger scale of coal utilization compared with other ores.

$\mathrm{EF}=\frac{(\mathrm{Hg} / S c) \text { coal }}{(H g / S c) \text { crust }}$

where, the concentration mean of scandium in Chinese coal and in the crust are 4.40 and $18 \mu \mathrm{g} / \mathrm{g}$, respectively.
(2) The distributions of mercury in Chinese coals

The distributions of mercury concentrations in coals of different coal-forming periods and coal-accumulating areas are shown in Tables 3 and 4 . The mercury concentrations vary largely in the coals of different coal-forming periods. The average concentration of mercury in coals of Triassic (T) is highest in all coal-forming periods. The average mercury concentrations in coals of Early Carboniferous $\left(\mathrm{C}_{1}\right)$, Late Permian $\left(\mathrm{P}_{2}\right)$ and Eogene $(\mathrm{E})$ are relatively higher than the average concentration of the Chinese coals. The average mercury concentrations in coals of Late Jurassic to Early Cretaceous $\left(\mathrm{J}_{3}-\mathrm{K}_{1}\right)$ and Early-Middle Jurassic $\left(\mathrm{J}_{1-2}\right)$ are relatively lower than $0.15 \mu \mathrm{g} / \mathrm{g}$. As the $\mathrm{T}$, $\mathrm{P}_{2}$ and $\mathrm{C}_{1}$ are the main coal-forming periods in South China while $\mathrm{J}_{3}-\mathrm{K}_{1}$ and $\mathrm{J}_{1-2}$ in Northeast and Northwest China respectively, the mercury concentrations in coals 
Table 6 The basic characteristics of coal samples studied

\begin{tabular}{|c|c|c|c|c|c|c|c|c|c|}
\hline \multirow[t]{2}{*}{ Samples } & \multicolumn{3}{|c|}{ Proximate analyses (wt, \%) } & \multirow[t]{2}{*}{$\mathrm{Hg}(\mu \mathrm{g} / \mathrm{g})$} & \multicolumn{4}{|c|}{ Maceral analysis (in volume, \%) } & \multirow[t]{2}{*}{$R_{\mathrm{o}, \max }(\%)$} \\
\hline & Ash yield & Volatile matter & Total Sulfur & & Vitrinite & Inertinite & Exinite & Minerals & \\
\hline XLT & 9.39 & 52.73 & 0.60 & 0.036 & 83.12 & 5.08 & 9.26 & 2.54 & 0.47 \\
\hline HLH & 25.56 & 48.42 & 0.56 & 0.250 & 69.91 & 5.64 & 1.88 & 22.56 & 0.33 \\
\hline $\mathrm{TF}$ & 46.40 & 42.06 & 0.33 & 0.086 & 62.44 & 6.01 & 3.67 & 27.87 & 0.65 \\
\hline YM & 21.31 & 41.13 & 2.61 & 0.240 & 54.91 & 29.45 & 3.37 & 12.27 & 0.47 \\
\hline SD & 7.02 & 36.84 & 0.42 & 0.090 & 45.02 & 51.66 & 1.40 & 1.92 & 0.51 \\
\hline DT & 14.66 & 31.07 & 1.79 & 0.300 & 27.54 & 63.68 & 1.79 & 6.98 & 0.81 \\
\hline PS & 18.69 & 39.08 & 0.52 & 0.290 & 47.69 & 33.16 & 10.09 & 9.06 & 0.70 \\
\hline HDG & 24.67 & 38.50 & 0.49 & 0.413 & 31.87 & 44.88 & 8.78 & 14.48 & 0.52 \\
\hline $\mathrm{CC}$ & 17.65 & 14.77 & 0.26 & 0.069 & 58.52 & 27.42 & 0.00 & 14.06 & 1.89 \\
\hline $\mathrm{YZ}$ & 14.60 & 46.23 & 4.00 & 0.210 & 69.98 & 18.81 & 4.98 & 7.23 & 0.62 \\
\hline
\end{tabular}

Notes Ash yield and total sulfur are on dry bases, volatile matter is on dry and ash free basis
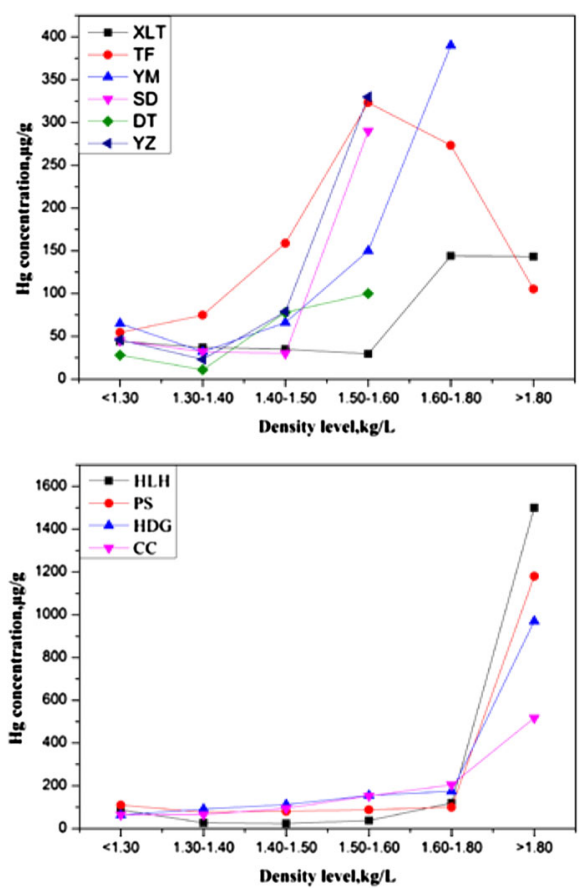

Fig. 5 The concentrations of mercury in different density fractions of float-sink experiments

from South China are relatively higher than those in North China in general.

The concentrations of mercury in coals of different ranks are shown in Fig. 2. There is no obvious relationship between mercury concentrations and the coal rank. But the mercury concentrations in meager coal and anthracite are relatively higher, with the arithmetic mean over $0.20 \mu \mathrm{g} / \mathrm{g}$, which is largely attributed to their deposited geological settings and the metamorphic process (Ren et al. 1999b). As most high-rank coals in southern China have suffered magma and hydrothermal intrusion during post- depositional stage, relatively higher mercury contents are found in those coals.

(3) The preliminary study on the relationship between mercury and minerals

The relationships between the concentrations of mercury and the ash yield, sulfur contents in coals of different coalforming periods and coal-accumulating areas are shown in Figs. 3 and 4 respectively. Mercury may be closely associated with minerals in coals, especially pyrite, as the mean concentrations of mercury and the ash yield, sulfur contents in coals of different coal-forming periods and coal-accumulating areas share the same trends. Extraordinary high sulfur concentrations are found in some $\mathrm{P}_{2}$ coals from South China and $\mathrm{C}_{3}$ coals from North China and the mercury concentrations are not as high as the sulfur content proportionately. Those coals are closely related to the hydrothermal activity during coal metamorphism.

\subsection{Modes of occurrence of mercury in Chinese coals}

(1) The distribution of mercury in different density fractions

The basic characteristics of the 10 coal samples studied are shown in Table 6 and the concentrations of mercury in different density fractions are shown in Fig. 5. The concentrations of mercury in the heaviest fraction are almost 10 times higher than that in the lightest fraction, especially for some coals from early Permian $\left(\mathrm{P}_{1}\right)$ in North China, such as PS, HDG and CC. So it can be easily concluded that mercury is mainly distributed in minerals for those coals. Besides, The concentrations of mercury in $<1.3 \mathrm{~kg} / \mathrm{L}$ fractions are apparently higher than that in $1.3-1.4 \mathrm{~kg} / \mathrm{L}$ fractions for most coals, which is also come to the case of 
Table 7 The correlation coefficients between mercury and macerals, ash yield and sulfur contents

\begin{tabular}{lrrrrrr}
\hline Sample & Vitrinite & Inertinite & Clay & Pyrite & $\begin{array}{l}\text { Ash } \\
\text { yield }\end{array}$ & $\begin{array}{l}\text { Total } \\
\text { sulfur }\end{array}$ \\
\hline XLT & 0.94 & -0.75 & -0.46 & -0.36 & 0.80 & -0.48 \\
HLH & -0.70 & -0.64 & 0.63 & 0.99 & 0.78 & 0.98 \\
TF & -0.41 & 0.81 & 0.40 & -0.09 & 0.29 & -0.12 \\
YM & -0.76 & -0.52 & 0.90 & 0.89 & 0.93 & 0.95 \\
SD & -0.55 & -0.59 & 0.97 & 0.98 & 0.97 & 0.98 \\
DT & -0.54 & -0.26 & 0.61 & 0.60 & 0.86 & 0.31 \\
PS & -0.47 & -0.58 & 0.89 & 0.99 & 0.80 & 0.96 \\
HDG & -0.42 & -0.36 & 0.87 & 0.94 & 0.90 & 0.83 \\
CC & -0.91 & -0.37 & 0.99 & 0.66 & 0.98 & -0.80 \\
YZ & -0.77 & -0.49 & 0.90 & 0.80 & 0.88 & 0.80 \\
\hline
\end{tabular}

Note Ash yield and total sulfur are on dry bases

Table 8 Calculated values of mercury in macerals and minerals

\begin{tabular}{|c|c|c|c|c|c|c|}
\hline \multirow[t]{2}{*}{ Samples } & \multicolumn{4}{|c|}{ Maceral or mineral component $(\mu \mathrm{g} / \mathrm{g})$} & \multicolumn{2}{|c|}{$\begin{array}{l}\text { Significance } \\
\text { testing }\end{array}$} \\
\hline & Vitrinite & Inertinite & Pyrite & Clay & $\mathrm{R}$ & $\mathrm{F}$ \\
\hline YM & 0.062 & 0.059 & 2.010 & -0.383 & 0.93 & 4.17 \\
\hline SD & 0.061 & 0.015 & \multicolumn{2}{|c|}{0.360} & 0.98 & 13.03 \\
\hline DT & 0.020 & 0.060 & \multicolumn{2}{|c|}{0.108} & 0.68 & 0.56 \\
\hline PS & 0.396 & -1.037 & \multicolumn{2}{|c|}{1.392} & 0.95 & 11.27 \\
\hline HDG & 0.128 & 0.114 & \multicolumn{2}{|c|}{0.412} & 0.32 & 0.15 \\
\hline $\mathrm{CC}$ & 0.015 & -0.079 & \multicolumn{2}{|c|}{0.574} & 0.98 & 51.98 \\
\hline $\mathrm{YZ}$ & \multicolumn{2}{|c|}{0.099} & -0.410 & 0.953 & 0.92 & 3.44 \\
\hline XLT & \multicolumn{2}{|c|}{0.022} & \multicolumn{2}{|c|}{0.248} & 0.80 & 5.38 \\
\hline HLH & \multicolumn{2}{|c|}{-0.368} & \multicolumn{2}{|c|}{1.607} & 0.78 & 4.57 \\
\hline $\mathrm{TF}$ & \multicolumn{2}{|c|}{0.124} & \multicolumn{2}{|c|}{0.180} & 0.16 & 0.08 \\
\hline
\end{tabular}

vitrinite. So the concentration of mercury in vitrinite is generally higher than in inertinite.

\section{(2) Correlation analysis}

The correlation coefficients between the concentrations of mercury and the petrographic constituents are shown in Table 7. It is generally considered that mercury mainly associated with sulfides in coals. Significant positive correlations lie between the concentration of mercury and total sulfur (or pyrite) in HLH, YM, SD and PS. Significant positive correlations lie between the concentration of mercury and ash yield (or clay mineral) in CC, YZ and DT, which indicated that mercury may be distributed in clay minerals as adsorbed state and isomorphism. Significant positive correlation lies between the concentration of mercury and the vitrinite in XLT, which indicated that mercury may dispersed in vitrinite as micro-fine particles or organically-bonded. Significant positive correlation lies between the concentration of mercury and the inertinite in $\mathrm{TF}$, which need further study. Generally, the mercury is mainly distributed in pyrite and clay minerals in Chinese coals, and the concentration in vitrinite is higher than that in inertinite.

(3) The theoretical concentrations and affinities of mercury in coals

The concentrations of mercury in vitrinite, inertinite and minerals of coals calculated by Eq. (2) are shown in Table 8. It can be seen that mercury is more enriched in minerals than in macerals for all samples. As the concentrations of mercury in vitrinite are usually higher than that in inertinite, mercury is accumulated in reducing environments rather than in oxidizing ones. The distributions of mercury are notably different between two high-sulfur

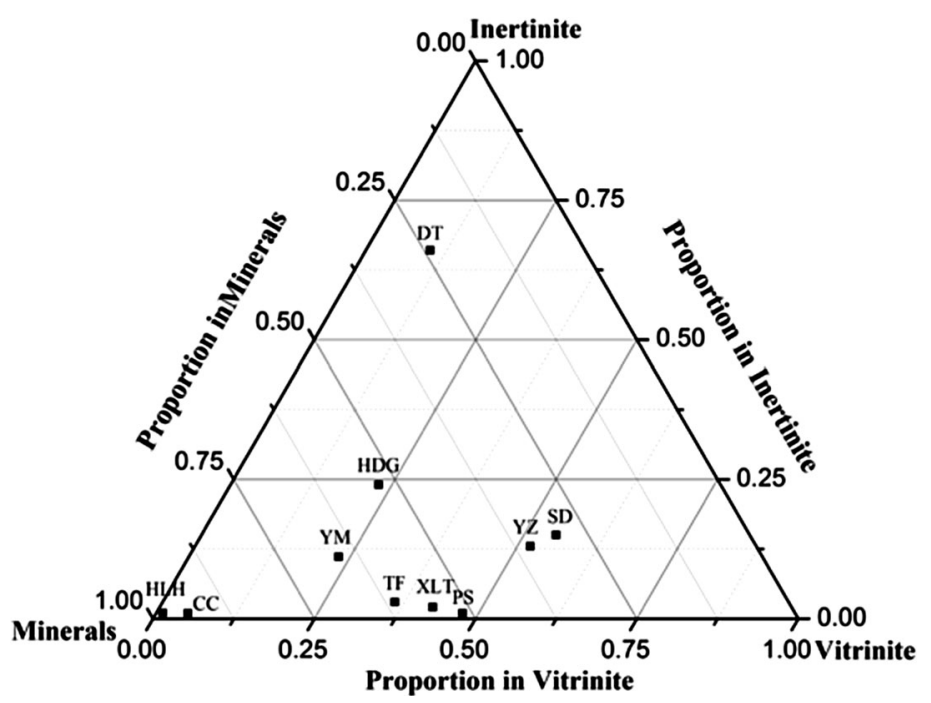

Fig. 6 Distribution of mercury in macerals and minerals of the coals studied 
coals samples of YM and YZ. Mainly distributed in epigenetic granular pyrite particles of fissure vein in YM coal, mercury can be easily removed during coal washing. The mercury in YZ coal is mainly distributed in clay minerals while the pyrite dispersed in fine size in vitrinite is syngenetic originated.

The affinity $\left(A_{i}\right)$ of mercury to vitrinite, inertinite and minerals of coals studied are shown in Fig. 6. It is easily concluded that mercury has higher affinities to minerals and vitrinite than inertinite.

In summary, the modes of occurrence of mercury are relatively complex and its affinity to minerals and macerals in different coals are different from each other. But there is a general trend that mercury occurs mainly in minerals, especially in epigenetic pyrite, and mercury is apt to be enriched in vitrinite rather than in inertinite.

\section{Conclusions}

The concentration and distribution characteristics of mercury in Chinese coals were studied with 1018 coal samples systematic collected around the country. The modes of occurrence of mercury are studied with float-sink experiments and correlation analyses of 10 representative coals of different rank from different basins in China. The main conclusions are as follows:

(1) The weighted average concentration of mercury in Chinese coals is $0.154 \mu \mathrm{g} / \mathrm{g}$, which is similar to the average value in the world coal.

(2) Geological settings played key roles in determining the geochemistry and mineralogy of coals, and the mercury concentrations in the coals of different coalforming period coal-accumulating areas are quite different. The concentrations of mercury in coals from south and southwest China and those from North China of $\mathrm{C}_{3}-\mathrm{P}_{1}$ are relatively higher while those from North China of $\mathrm{J}_{1-2}$ and Northeast of $\mathrm{J}_{3^{-}}$ $\mathrm{K}_{1}$ relatively lower. The general distributions of mercury are very similar to that of ash yield, sulfur contents in coals from different coal-forming periods and coal-accumulating areas.

(3) The modes of occurrence of mercury are relatively complex in Chinese coals. Correlation analyses and calculations have indicated that mercury occurs mainly in minerals, especially in pyrite. Mercury is apt to be enriched in vitrinite rather than in inertinite.

Acknowledgements The authors thank Beijing Research Institute of Coal Chemistry for supplying the original data on the concentration of mercury in Chinese coals from "Chinese Coal Resource Database". Financial support for this work by National Key Research and Development Program of China (2016YFB0600301) is gratefully acknowledged. Special thanks are given to two anonymous reviewers for their useful suggestions and comments.

Open Access This article is distributed under the terms of the Creative Commons Attribution 4.0 International License (http://crea tivecommons.org/licenses/by/4.0/), which permits unrestricted use, distribution, and reproduction in any medium, provided you give appropriate credit to the original author(s) and the source, provide a link to the Creative Commons license, and indicate if changes were made.

\section{References}

Bai XF (2003) The distributions, modes of occurrence and volatility of trace elements in coals of China. Doctor's thesis, China Coal Research Institute

Bai XF, Li WH, Chen YF, Jiang Y (2007) The general distributions of trace elements in Chinese coals. Coal Qual Technol 1:1-4

Brownfield ME, Affolter RH, Cathcart JD, Johnson SY, Brownfield IK, Rice CA, Zielinski RA (2005) Geologic setting and characterization of coal and the modes of occurrence of selected elements from the Franklin coal zone, Puget Group, John Henry No. 1 mine, King county, Washington. Int J Coal Geol 63:247-275

Chen J, Chen P, Yao DX, Liu Z, Wu YS, Liu WZ, Hu YB (2015) Mineralogy and geochemistry of Late Permian coals from the Donglin Coal Mine in the Nantong coalfield in Chongqing, southwestern China. Int J Coal Geol 149:24-40

Clarke LB, Sloss LL (1992) Trace elements-emissions from coal combustion and gasification. IEA Coal Research, London

Dai SF, Ren DY (2007) Effects of magmatic intrusion on mineralogy and geochemistry of coals from the Fengfeng-Handan Coalfield, Hebei, China. Energ Fuel 21:1663-1673

Dai SF, Ren DY, Chou CL, Li SS, Jiang YF (2006a) Mineralogy and geochemistry of the No. 6 Coal (Pennsylvanian) in the Junger Coalfield, Ordos Basin. China. Int J Coal Geol 66:253-270

Dai SF, Zeng RS, Sun YZ (2006b) Enrichment of arsenic, antimony, mercury, and thallium in a late Permian anthracite from Xingren, Guizhou, southwest China. Int J Coal Geol 66:217-226

Dai SF, Ren DY, Zhou YP, Chou CL, Wang XB, Zhao L, Zhu XW (2008) Mineralogy and geochemistry of a superhigh-organicsulfur coal, Yanshan Coalfield, Yunnan, China: evidence for a volcanic ash component and influence by submarine exhalation. Chem Geol 255:182-194

Dai SF, Ren DY, Chou CL, Finkelman RB, Seredin VV, Zhou YP (2012a) Geochemistry of trace elements in Chinese coals: a review of abundances, genetic types, impacts on human health, and industrial utilization. Int J Coal Geol 94:3-21

Dai SF, Wang XB, Seredin VV, Hower JC, Ward CR, O'Keefe JMK, Huang WH, Li T, Li X, Liu HD, Xue WF, Zhao LX (2012a) Petrology, mineralogy, and geochemistry of the Ge-rich coal from the Wulantuga Ge ore deposit, Inner Mongolia, China: new data and genetic implications. Int J Coal Geol 90/91: 72-99

Dai SF, Zou JH, Jiang YF, Ward CR, Wang XB, Li T, Xue WF, Liu SD, Tian HM, Sun XH, Zhou D (2012c) Mineralogical and geochemical compositions of the Pennsylvanian coal in the Adaohai Mine, Daqingshan Coalfield, Inner Mongolia, China: modes of occurrence and origin of diaspore, gorceixite, and ammonian illite. Int J Coal Geol 94:250-270

Dai SF, Zhang WG, Ward CR, Seredin VV, Hower JC, Li X, Song WJ, Wang XB, Kang H, Zheng LC, Wang PP, Zhou D (2013a) Mineralogical and geochemical anomalies of late Permian coals from the Fusui Coalfield, Guangxi Province, southern China: influences of terrigenous materials and hydrothermal fluids. Int $\mathrm{J}$ Coal Geol 105:60-84 
Dai SF, Zhang WG, Seredin VV, Ward CR, Hower JC, Song WJ, Wang XB, Li X, Zhao LX, Kang H, Zheng LC, Wang PP, Zhou D (2013b) Factors controlling geochemical and mineralogical compositions of coals preserved within marine carbonate successions: a case study from the Heshan Coalfield, southern China. Int J Coal Geol 109/110: 77-100

Dai SF, Luo YB, Seredin VV, Ward CR, Hower JC, Zhao L, Liu SD, Zhao CL, Tian HM, Zou JH (2014) Revisiting the late Permian coal from the Huayingshan, Sichuan, southwestern China: enrichment and occurrence modes of minerals and trace elements. Int J Coal Geol 122:110-128

Dai SF, Li TJ, Jiang YF, Ward CR, Hower JC, Sun JH, Liu JJ, Song HJ, Wei JP, Li QQ, Xie PP, Huang Q (2015) Mineralogical and geochemical compositions of the Pennsylvanian coal in the Hailiushu Mine, Daqingshan Coalfield, Inner Mongolia, China: implications of sediment-source region and acid hydrothermal solutions. Int J Coal Geol 137:92-110

Diehl SF, Goldhaber MB, Koenig AE, Lowers HA, Ruppert LF (2012) Distribution of arsenic, selenium, and other trace elements in high pyrite Appalachian coals: evidence for multiple episodes of pyrite formation. Int J Coal Geol 94:238-249

Finkelman RB (1994) Modes of occurrence of potentially hazardous elements in coal: levels of confidence. Fuel Process Technol 39:21-34

Finkelman RB, Bostick NH, Dulong FT, Senftle FE, Thorpe AN (1998) Influence of an igneous intrusion on the inorganic geochemistry of a bituminous coal from Pitkin County, Colorado. Int J Coal Geol 36:223-241

Fitzgerald WF, Engstrom DR, Mason RP, Nater EA (1998) The case for atmospheric mercury contamination in remote areas. Environ Sci Technol 32:1-7

Galbreath KC, Zygarlicke CJ (2000) Mercury transformations in coal combustion flue Gas. Fuel Process Technol 65/66:289-310

Golab AN, Carr PF (2004) Changes in geochemistry and mineralogy of thermally altered coal, Upper Hunter Valley, Australia. Int J Coal Geol 57:197-210

Grasby SE, Sanei H, Beauchamp B, Chen ZH (2013) Mercury deposition through the Permo-Triassic Biotic Crisis. Chem Geol 351:209-216

Grasby SE, Beauchamp B, Bond DPG, Wignall PB, Sanei H (2015) Mercury anomalies associated with three extinction events (Capitanian Crisis, Latest Permian Extinction and the Smithian/Spathian Extinction) in NW Pangea. Geol Mag 153(2):1-13

Hower JC, Robertson JD (2003) Clausthalite in coal. Int J Coal Geol 53:219-225

Hower JC, Ruppert LF, Eble C (2007) Lateral variation in geochemistry, petrology, and palynology in the Elswick coal bed, Pike County, Kentucky. Int J Coal Geol 69:165-178

Hower JC, Campbell JL, Teesdale WJ, Nejedly Z, Robertson JD (2008) Scanning proton microprobe analysis of mercury and other trace elements in Fe-sulfides from a Kentucky coal. Int J Coal Geol 75:88-92

Huang WH, Yang YC (2002) Mercury in coal of China. Coal Geol China 14:37-40

Huang WJ, Qu Z, Chen WM, Xu HM, Yan NQ (2016) An enhancement method for the elemental mercury removal from coal-fired flue gas based on novel discharge activation reactor. Fuel 171:59-64

Jiang YF, Zhao L, Zhou GQ, Wang XB, Zhao LX, Wei JP, Song HJ (2015) Petrological, mineralogical, and geochemical compositions of Early Jurassic coals in the Yining Coalfield, Xinjiang, China. Int J Coal Geol 152:47-67

Ketris MP, Yudovich YE (2009) Estimations of Clarkes for carbonaceous biolithes: world averages for trace element contents in black shales and coals. Int J Coal Geol 78:135-148
Kolker A (2012) Minor element distribution in iron disulfides in coal: a geochemical review. Int J Coal Geol 94:32-43

Kongchum M, Hudnall WH, Delaune RD (2011) Relationship betweensediment clay minerals and total mercury. J Environ Sci Health A 45:534-539

Li J, Zhuang XG, Querol X, Font O, Moreno N, Zhou JB, Lei GM (2012) High quality of Jurassic Coals in the Southern and Eastern Junggar Coalfields, Xinjiang, NW China: geochemical and mineralogical characteristics. Int J Coal Geol 99:1-15

Li BQ, Zhuang XG, Li J, Querol X, Font O, Moreno N (2016) Geological controls on mineralogy and geochemistry of the Late Permian coals in the Liulong Mine of the Liuzhi Coalfield, Guizhou Province, Southwest China. Int J Coal Geol 154/155: $1-15$

Liu YJ, Cao LM (1987) Introduction to geochemistry of element. Geological Publishing House, Beijing

Liu GJ, Zheng LG, Zhang Y, Qi CC, Chen YW, Peng ZC (2007) Distribution and mode of occurrence of $\mathrm{As}, \mathrm{Hg}$ and $\mathrm{Se}$ and Sulfur in coal Seam 3 of the Shanxi Formation, Yanzhou Coalfield, China. Int J Coal Geol 71:371-385

Mao JH, Xu HL (1999) The survey and evaluation of coal resource in China. Science Press, Beijing

Mu BL (1999) Geochemistry of element. Peking University Press, Beijing

Outridge PM, Sanei H (2010) Does organic matter degradation affect the reconstruction of pre-industrial atmospheric mercury deposition rates from peat cores? A test of the hypothesis using a permafrost peat deposit in northern Canada. Int $\mathbf{J}$ Coal Geol 83:73-81

Pacyna EG, Pacyna JM, Steenhuisen F, Wilson S (2006) Global anthropogenic mercury emission inventory for 2000. Atmos Environ 40:4048-4063

Pacyna E, Pacyna J, Sundseth K, Munthe J, Kindbom K, Wilson S, Steenhuisen F, Maxson P (2010) Global emission of mercury to the atmosphere from anthropogenic sources in 2005 and projections to 2020. Atmos Environ 44:2487-2499

Pirrone N, Cinnirella S, Feng X, Finkelman RB, Friedli H, Leaner R (2010) Global mercury emissions to the atmosphere from anthropogenic and natural sources. Atmos Chem Phys 10: 5951-5964

Ren DY, Zhao FH, Wang YQ, Yang SJ (1999a) Distributions of minor and trace elements in Chinese coals. Int Coal Geol 40(2/ 3):109-118

Ren DY, Zhao FH, Zhang JY, Xu DW (1999b) A preliminary study on genetic type of enrichment for hazardous minor and trace elements in coal. Earth Sci Front 6(Supp 1):17-22

Rumayor M, Lopez-Anton MA, Díaz-Somoano M, Martínez-Tarazona MR (2015) A new approach to mercury speciation in solids using a thermal desorption technique. Fuel 160:525-530

Sanei H, Goodarzi F (2006) Relationship between organic matter and mercury in recent lake sediment: the physical-geochemical aspects. Appl Geochem 21:1900-1912

Sanei H, Goodarzi F, Outridge PM (2010) Spatial distribution of mercury and other trace elements in recent lake sediments from central Alberta, Canada: an assessment of the regional impact of coal-fired power plants. Int J Coal Geol 82:105-115

Sanei H, Outridge PM, Stern GA, Macdonald RW (2014) Classification of mercury-labile organic matter relationships in lake sediments. Chem Geol 373:87-92

Solari JA, Fiedler H, Schneider CL (1989) Modelling of the distribution of trace elements in coal. Fuel 68(4):536-539

Song DY, Qin Y, Zhang JY, Wang WF, Zheng CG (2007) Concentration and distribution of trace elements in some coals from Northern China. Int J Coal Geol 69:179-191

Sunderland EM, Mason RP (2006) Human impacts on open ocean mercury concentrations. Global Biogeochem Cycles 21(4):1-15 
Tang SL, Wang LN, Feng XB, Feng ZH, Li RY, Fan HP, Li K (2016) Actual mercury speciation and mercury discharges from coalfired power plants in Inner Mongolia, Northern China. Fuel 180:194-204

Thibodeau AM, Ritterbush K, Yager JA, WestA J, Ibarra Y, Bottjer DJ, Berelson WM, Bergquist BA, Corsetti FA (2016) Mercury anomalies and the timing of bioticrecovery following the endTriassic mass extinction. Nature Communications 7:1-8

UNEP Chemicals Branch (2013) Global Mercury Assessment 2013: Sources, Emissions. Releases and Environmental Transport, Geneva

Wang XB (2009) Geochemistry of Late Triassic coals in the Changhe Mine, Sichuan Basin, southwestern China: evidence for authigenic lanthanide enrichment. Int J Coal Geol 167-174

Wang WF, Qin Y, Sang SX, Jiang B, Zhu YM, Guo YH (2007) Sulfur variability and element geochemistry of the No. 11 coal seam from the Antaibao mining district, China. Fuel 86:777-784

Wang XB, Dai SF, Chou CL, Zhang MQ, Wang JM, Song XL, Wang W, Jiang YF, Zhou YP, Ren DY (2012) Mineralogy and geochemistry of Late Permian coals from the Taoshuping Mine, Yunnan Province, China: evidences for the sources of minerals. Int J Coal Geol 96/97:49-59

Ward CR, Spears DA, Booth CA, Staton I, Gurba LW (1999) Mineral matter and trace elements in coals of the Gunnedah Basin, New South Wales, Australia. Int J Coal Geol 40:281-308

Wilcox J, Rupp E, Ying SC, Lim DH, Negreira AS, Kirchofer A, Feng F, Lee K (2012) Mercury adsorption and oxidation in coal combustion and gasification processes. Int J Coal Geol 90:4-20
Yudovich YE, Ketris MP (2005) Mercury in coal: a review. Part 1. Geochemistry. Int J Coal Geol 62:107-134

Zhang JY (1999) The enrichment of potential hazardous trace elements in coals and their pollution control. Doctor's Thesis, China University of Mining and Technology (Beijing)

Zhang JY, Ren DY, Zheng CG, Zeng RS, Chou CL, Liu J (2002) Trace element abundances in major minerals of Late Permian coals from southwestern Guizhou Province, China. Int J Coal Geol 53:55-64

Zhao FH (1997) The mechanism of distribution and modes of occurrence of hazardous trace elements in coals and leaching experiments of coal combustion products. Doctor's Thesis, China University of Mining and Technology (Beijing)

Zhao JY, Tang XY, Huang WH (2002) Abundance of trace elements in coal of China. Coal Geol China 14:5-13

Zheng LG, Liu GJ, Chou CL, Qi CC, Zhang Y (2007) Geochemistry of rare earth elements in Permian coals from the Huaibei Coalfield, China. J Asian Earth Sci 31:167-176

Zheng LG, Liu GJ, Chou CL (2008) Abundance and modes of occurrence of mercury in some low-sulfur coals from China. Int J Coal Geol 73:19-26

Zhuang XG, Su SC, Xiao MG, Li J, Alastuey A, Querol X (2012) Mineralogy and geochemistry of the Late Permian coals in the Huayingshan coal-bearing area, Sichuan Province, China. Int J Coal Geol 94:271-282 